\title{
An Empirical Assessment of the Influence of Customers Emotions and Contact Employee Performance on Encounter and Relationship Satisfaction
}

Citation for published version (APA):

van Dolen, W. M., de Ruyter, J. C., \& Lemmink, J. G. A. M. (2004). An Empirical Assessment of the Influence of Customers Emotions and Contact Employee Performance on Encounter and Relationship Satisfaction. Journal of Business Research, 57(4), 437-444. https://doi.org/10.1016/S01482963(02)00277-1

Document status and date:

Published: 01/01/2004

DOI:

10.1016/S0148-2963(02)00277-1

Document Version:

Publisher's PDF, also known as Version of record

Please check the document version of this publication:

- A submitted manuscript is the version of the article upon submission and before peer-review. There can be important differences between the submitted version and the official published version of record. People interested in the research are advised to contact the author for the final version of the publication, or visit the DOI to the publisher's website.

- The final author version and the galley proof are versions of the publication after peer review.

- The final published version features the final layout of the paper including the volume, issue and page numbers.

Link to publication

\footnotetext{
General rights rights.

- You may freely distribute the URL identifying the publication in the public portal. please follow below link for the End User Agreement:

www.umlib.nl/taverne-license

Take down policy

If you believe that this document breaches copyright please contact us at:

repository@maastrichtuniversity.nl

providing details and we will investigate your claim.
}

Copyright and moral rights for the publications made accessible in the public portal are retained by the authors and/or other copyright owners and it is a condition of accessing publications that users recognise and abide by the legal requirements associated with these

- Users may download and print one copy of any publication from the public portal for the purpose of private study or research.

- You may not further distribute the material or use it for any profit-making activity or commercial gain

If the publication is distributed under the terms of Article 25fa of the Dutch Copyright Act, indicated by the "Taverne" license above, 


\title{
An empirical assessment of the influence of customer emotions and contact employee performance on encounter and relationship satisfaction
}

\author{
Willemijn van Dolen*, Ko de Ruyter, Jos Lemmink \\ Department of Marketing and Marketing Research, Faculty of Economics and Business Administration, Maastricht University, \\ P.O. Box 616, 6200 MD Maastricht, The Netherlands
}

\begin{abstract}
Our study examines the effect of customer emotions and contact employee performance in creating encounter and relationship satisfaction. It investigates the performance of the contact employee from an interactive perspective by specifying the employee performance into employee-specific and interaction-induced behaviors, using a multilevel approach. Our results reveal a significant influence of positive emotions on both types of satisfaction and no significant impact of negative emotions. Furthermore, our study identifies that not all of the employee behaviors that influence encounter satisfaction also influence relationship satisfaction. Additionally, results of the study demonstrate that specifying employee performance into employee-specific and interaction-induced behaviors allows a better understanding of customer encounter and relationship satisfaction.
\end{abstract}

(C) 2002 Elsevier Inc. All rights reserved.

Keywords: Emotions; Encounter satisfaction; Relationship satisfaction; Contact employee performance

\section{Introduction}

Customer satisfaction has received considerable attention in the marketing literature and practice in recent years (Oliver, 1997; Westbrook and Oliver, 1991; Price et al., 1995a). It affects several desirable outcomes like customer loyalty, worth-of-mouth promotion, and purchases (e.g., Fornell, 1992; Oliver and Swan, 1989). As such, increasing attention is given to customer satisfaction as a corporate goal, in addition to traditional financial measures of success.

The concept of customer satisfaction has relevance to both single, discrete encounters and to relationships. Often, in retail firms, the contact employee is the primary contact point for the customer before, during, and after the purchase. By having close contact to the customer, employees strongly influence the customer's experience and create encounter and relationship satisfaction, concepts which appear to be quite distinct from the customer's point of view (Bitner and Hubbert, 1994). Although research has suggested that contact employee performance is critical to create customer satisfaction, little has been done to analyze which employee behaviors influence customer encounter satisfaction and which

\footnotetext{
* Corresponding author. Tel.: +31-43-3883839; fax: +31-43-3884918.

E-mail address: w.vandolen@mw.unimaas.nl (W. van Dolen).
}

behaviors influence relationship satisfaction. Our study examines the key dimensions of employee performance in creating these two different types of satisfaction.

Furthermore, the literature on contact employee performance has identified a need to include interactive properties (Goff et al., 1997). The interactive nature of contact employee performance relates to the fact that the display of some behaviors of the contact employee is more dependent on the customer than others (Crosby et al., 1990). In other words, some behaviors of the contact employee are produced and performed by the contact employee alone, and are so-called employee-specific. However, some behaviors are interaction-induced, as they are more reactive and reciprocal in nature and are coproduced with the customer.

So far, little has been done in specifying the effect of this difference in contact employee's behavior on customer satisfaction. One possible explanation may be that to investigate these specific properties we should isolate those behaviors that are employee specific from the behaviors that are coproduced with the customer. Methodologically, this means that employee behavior should be measured at two levels: one aggregate level to measure employee-specific behaviors and an individual level to measure interaction-induced behaviors. With the advent of multilevel modeling, it has now become possible to differentiate 
between these behaviors, providing an integral perspective of the influence of employee behaviors on customer satisfaction at the encounter and at the relationship level. Such a perspective is taken in this paper.

Finally, research has shown that satisfaction in consumer contexts responds to both cognitive knowledge like evaluations of contact employee performance and to the emotions customers experience. Because of this suggested influence of affective and cognitive components on the formation of customer satisfaction, this study focuses on both.

This article is structured as follows. First, we offer a brief overview of the literature on key conceptual issues concerning customer satisfaction and the customer-contact employee interaction. We subsequently develop and test a two-level model to determine what employee-specific and interaction-induced antecedents influence encounter and relationship satisfaction of customers. We conclude with a discussion of research and managerial implications of our results.

\section{Customer satisfaction}

Research suggests that customers distinguish between encounter and relationship satisfaction. Encounter satisfaction will result from the evaluation of the events and behaviors that occur during a single, discrete interaction. Overall satisfaction, on the other hand, is viewed as a function of satisfaction with multiple experiences or encounters with the firm (Bitner and Hubbert, 1994). In earlier research, a number of different concepts have been used, related to these two different types of satisfaction; "transaction specific/global," "transaction specific/brand specific," and "episode/relationship" (e.g., Liljander and Strandvik, 1995). The commonality between them is the distinction between evaluations related to a discrete experience and evaluations related to an overall experience. In this study, we use the terms encounter and relationship satisfaction.

Furthermore, the formation of customer satisfaction can be described as a cognitive process, where customers consider whether their product, service, and process needs are addressed. On the other hand, satisfaction is believed to be created by an affective process, too (e.g., Oliver, 1997; Westbrook, 1987). This influence of both cognition and affect on the consumption experience is called the two-appraisal model (Oliver, 1997). The cognitive system performs the higher mental processes of understanding, evaluating, planning, deciding, and thinking, whereas affect refers to feeling responses. Although several approaches exist to describe emotions (e.g., the discrete approach of Izard, 1977), an emerging body of theory and evidence is available to suggest that the two dimensions, positive and negative affect, are useful in understanding the affective basis for the satisfaction response (e.g., Oliver, 1997). However, little has been done to analyze whether positive and negative emotions, evoked during an interaction, influence customer encounter satisfac- tion as well as relationship satisfaction. Therefore, we have focused on the following research question:

$\mathrm{RQ}_{1}$ : Do positive emotions have a positive impact and negative emotions a negative impact on customer encounter as well as on relationship satisfaction?

The customers' cognitive evaluations of the interaction experience are studied as customer's perceptions of contact employee performance. Whether the focus is on encounter satisfaction or on relationship satisfaction, the performance of the contact employee is critical to satisfaction (Crosby et al., 1990). At the encounter level, the behavior of the contact employee plays a critical role in diagnosing and addressing customer's needs and in shaping the overall evaluation of the way in which the discrete exchange is executed (Szymanski, 1988; Spiro and Weitz, 1990). At the relationship level, research found that customer-oriented employees which show empathy, understanding for the customer, interpersonal care, and trustworthy behavior, and provide augmented personal service, are critical to long-term relationship building (e.g., Beatty et al., 1996).

The performance of a contact employee during interactions with customers has been the subject of considerable research, in both sales and service settings. According to this research, a contact employee role should incorporate both relational aspects and core task aspects (e.g., Czepiel, 1990; Crosby et al., 1990; Reynolds and Beatty, 1999). Recently, researchers have conducted several studies to improve the indices of contact employee performance (Winsted, 1997; Price et al., 1995b). Price et al. (1995b) propose five dimensions of contact employee behavior that influence customer's perceptions: mutual understanding, authenticity, extra attention, competence, and meeting minimum standards.

While employee performance has been studied extensively, very little research has explored which employee behaviors during an interaction influence customer encounter satisfaction and which behaviors influence relationship satisfaction. Therefore, we have focused on the following research question:

$\mathrm{RQ}_{2}$ : Which of the specific contact employee performance dimensions influence encounter and which influence relationship satisfaction?

In the next section, we will elaborate on the role of employee performance in interactions with the customer.

\section{Contact employee interaction}

We subscribe to the importance of the performance dimensions as suggested by Price et al. (1995b). However, a more comprehensive approach to measure performance would be a model that takes the interactive nature of the encounter into account. The interactive nature of an encounter implies that the display of some behaviors of the contact employee is more dependent on the customer than others, 
because of their more reciprocal nature (Crosby et al., 1990). For example, authenticity, defined as being genuine, is more under control of the contact employee, than mutual understanding; connecting with customers' lives and inviting and sharing personal exchanges seems to us difficult without an active role of the customer.

We call the behaviors that are produced and performed by the contact employee alone employee-specific behaviors. After a close examination of the dimensions of contact employee performance of Price et al. (1995b), we suggest that competence and authenticity are employee specific.

Competence has often been noted as an attribute of the contact employee (Crosby et al., 1990) and as static property of the contact employee dyad (e.g., Weitz et al., 1986). It goes to the core of what is expected of the contact employee during the interaction and defines the extent to which the individual provider can affect the outcome of the interaction through his or her skills. Customers seek to obtain advice and information of the employee that requires an expertise they lack (Johnson and Zinkham, 1991). This implies that the competence of the contact employee is a resource of the employee during the interaction irrespective of the input of the customer. Also, the dyadic decision-making research literature suggest that aspects of competence like being capable, organized, and efficient are variables which an individual brings, autonomously, to the interaction (Jaccard et al., 1989).

Authenticity relates to individuals who present their real selves in interactions (e.g., Gurevitch, 1985; Price et al., 1995b). It defines the extent to which the employee is genuine and his/her own person. We think that contact employees present their true self alone and that a contribution of the customer is not needed.

The performance of these behaviors may be influenced, in part, by the contextual demands of the interaction. However, in line with the dyadic decision-making research, we posit that because of their independent nature, employeespecific variables are predictive of the occurrence of particular events within the interaction (e.g., Jaccard et al., 1989). In this way, these behaviors refer to an individual's performance tendency and to relatively stable behaviors that are active in interactions. For example, contact employees who are competent and ordered will structure the encounter, keep materials methodically organized and are thorough in their approach, regardless of the situational inputs.

We call the behaviors that are coproduced with the customer interaction-induced behaviors. These behaviors are reactive and reciprocal in nature and exist by the interaction. Examples of these behaviors are a contact employee's response to special requests, meeting customer's needs, and sharing of personal information between customer and contact employee. With regard to the dimensions of performance of Price et al. (1995b), we suggest that mutual understanding, extra attention, and meeting minimum standards are interaction induced.

Mutual understanding is achieved when both the contact employee and the customer engage in self-disclosure (Price et al., 1995a) and is only attained by the norm of reciprocity (Gouldner, 1960). Extra attention, in this study, relates to the contact employee's responses to customer's explicit or inferred requests for customized treatment (Bitner et al., 1990; Price et al., 1995b). Arguably, a response can only happen in reaction to an action of the customer. Also, meeting minimum standards is reactive and related to the contact employee's responses to needs and requests of customers. However, this relates to responses to meet the basic performance standards for contact employees in the industry, like giving basic information about products (Bitner et al., 1990).

Although many researchers acknowledge the interactive nature of the encounter, only a few studies take this aspect into account. In our study, we have focused on the following research question:

$\mathrm{RQ}_{3}$ : Do authenticity and competence influence encounter and relationship satisfaction at the employee level and extra attention, meeting minimum standards, and mutual understanding at the interaction level?

Next, an empirical study was designed to explore the research questions.

\section{An empirical study}

\subsection{Research setting}

The research was conducted among customers of a large Dutch furniture company. The company's furniture shops were selected as a research setting because of the discrete nature of their services. Discrete services can be characterized as services that consist of distinct encounters for which the customer has to decide each time whether or not to continue the relationship. This makes it indeed relevant to focus on encounter as well as on relationship satisfaction. Furthermore, the selling of furniture is often preceded by complementary service suggestions by the contact employee regarding home remodeling and home decoration. As a consequence, the interaction between the customer and contact employee is intense and customers are highly involved. Customers need information about materials, colors, style, and maintenance, and often a lot of money is spent during a visit. In such interactions, the performance of the contact employee is important and emotions may play a determining role in creating a memorable experience for the customer.

\subsection{Questionnaire development}

\subsubsection{Customer satisfaction}

Encounter satisfaction was measured with two disconfirmation items which could be answered on a worse than, better than expected, seven-point scale. In addition, six items were measured with a seven-point Likert scale ranging from totally disagree to totally agree, all as suggested by Oliver (1997). Relationship satisfaction was measured by 
Table 1

Scale items

\begin{tabular}{|c|c|c|}
\hline Scale & Cronbach's alpha & Item \\
\hline $\begin{array}{l}\text { Encounter } \\
\text { satisfaction }\end{array}$ & .89 & $\begin{array}{l}\text { This was one of the best encounters } \\
\text { I could have had } \\
\text { This encounter was exactly } \\
\text { what I needed } \\
\text { I am satisfied with this encounter } \\
\text { I have truly enjoyed this encounter } \\
\text { This encounter was a good } \\
\text { experience } \\
\text { I am not happy with this encounter } \\
\text { (reverse coded) } \\
\text { In comparison to what I expected, } \\
\text { I found the encounter } \\
\text { In comparison to what I expected, } \\
\text { I found the contact employee }\end{array}$ \\
\hline $\begin{array}{l}\text { Relationship } \\
\text { satisfaction }\end{array}$ & .81 & $\begin{array}{l}\text { I am satisfied with company } \mathrm{X} \\
\text { In comparison to what I expected, } \\
\text { company } \mathrm{X} \text { performs }\end{array}$ \\
\hline $\begin{array}{l}\text { Positive } \\
\text { emotions }\end{array}$ & .78 & $\begin{array}{l}\text { Attentive } \\
\text { Alert } \\
\text { Concentrated } \\
\text { Joyful } \\
\text { Delighted } \\
\text { Happy }\end{array}$ \\
\hline $\begin{array}{l}\text { Negative } \\
\text { emotions }\end{array}$ & .79 & $\begin{array}{l}\text { Downhearted } \\
\text { Sad } \\
\text { Discouraged } \\
\text { Enraged } \\
\text { Angry } \\
\text { Mad } \\
\text { Scared } \\
\text { Fearful } \\
\text { Afraid }\end{array}$ \\
\hline $\begin{array}{l}\text { Mutual } \\
\text { understanding }\end{array}$ & .76 & $\begin{array}{l}\text { The contact employee: } \\
\text { Connected to my life/experiences } \\
\text { Revealed personal information } \\
\text { Invited me to reveal } \\
\text { personal information }\end{array}$ \\
\hline Extra attention & .70 & $\begin{array}{l}\text { Paid special attention to me } \\
\text { Went out of his/her way } \\
\text { Gave me a break (something extra) }\end{array}$ \\
\hline Authenticity & .91 & $\begin{array}{l}\text { Was truly out of the ordinary } \\
\text { Was genuine } \\
\text { Was his/her own person }\end{array}$ \\
\hline Competence & .92 & $\begin{array}{l}\text { Was capable } \\
\text { Was efficient } \\
\text { Was organized } \\
\text { Was thorough }\end{array}$ \\
\hline $\begin{array}{l}\text { Meeting } \\
\text { minimum }\end{array}$ & .71 & $\begin{array}{l}\text { Met my needs } \\
\text { Violated proper behavior } \\
\text { (reverse coded) } \\
\text { Performed as I expected }\end{array}$ \\
\hline
\end{tabular}

one satisfaction item and one disconfirmation question. A listing of items comprising these scales, along with Cronbach's alpha, is provided in Table 1 .

\subsubsection{Emotions}

Two scales measured respondent's emotional response to the encounter. The items used to measure emotion are based on the Differential Emotions Scale (DES) of Izard (1977, 1991). Izard's DES is often used in customer satisfaction research. Izard proposes 10 discrete, basic emotions; two positive, seven negative, and one affect-neutral. However, there is increasing evidence that, in applications like ours, emotions can best be characterized in terms of two independent dimensions: positive and negative. Izard also distinguishes the positive from the negative ones. Based on this distinction, the positive emotion scale for this study consists of interest and joy. Negative emotions were measured by the negative emotions of the DES. However, a disadvantage of the DES is that it overemphasizes negative affect, measuring it with 21 items. To get a scale with a sense of balance between positive and negative emotions, we ignored that discrete emotion with an ill fit in the present context, disgust. Besides, we decided to omit those emotions of which fewer theorist agree on the degree to which these emotions can be considered basic (contempt, shame, and guilt), because they have a substantial cognitive content (Oliver, 1997). The discrete emotions left to measure negative emotions are sadness, anger, and fear. Respondents indicated to what extent they experienced a certain emotion during the interaction with the contact employee on a five-point response scale ranging from not at all to very much. Surprise is left out of both scales because this emotion is affect-neutral in that it can be positive or negative. Many researchers provide evidence on the reliability and validity of DES (e.g., Westbrook, 1987; Oliver, 1997). A listing of items comprising these scales, along with Cronbach's alpha, is provided in Table 1.

\subsubsection{Contact employee performance}

Contact employee performance was measured with the five performance dimensions of Price et al. (1995b). These dimensions are mutual understanding, extra attention, authenticity, competence, and meeting minimum standards. The scales have been found to have an adequate reliability and validity (Price et al., 1995b). The response format was a seven-point scale ranging from totally disagree to totally agree.

Mutual understanding measures the extent to which the interaction with the contact employee is experienced as communicating empathy and understanding.

Extra attention measures the extent to which the contact employee offered extra attention to the customer in the encounter.

Authenticity measures the extent to which the customer perceives the contact employee as authentic.

Competence measures the functional dimensions of the contact employee performance.

Meeting minimum standards measures the extent to which the contact employee meets minimum standards of civility.

A listing of items comprising these scales, along with Cronbach's alpha, is provided in Table 1. In addition to these constructs regarding the role of the contact employee, the demographic variables age, gender, and experience of the contact employee served as control variables.

All items used in the questionnaire were translated into Dutch. Regarding this, the following process was conducted. 
First, we collected all items in their original English version. Then, the items were translated into Dutch by the researchers. Next, the questionnaire was retranslated into English by a language institute, which had not participated in the development of our questionnaire. The retranslated English version was compared to the original English version. Only a few items were different. For these items, a second opinion was asked from another language institute. During the whole process, the Dutch items were pretested among random selected people to ensure that the items were clear.

\subsection{Sampling and surveying}

The sample of respondents includes only customers that have visited the furniture shop at least three times in the past year. Consequently, these customers have developed a relationship with the store. The customers completed the questionnaires in the store, immediately after an encounter with a contact employee. Accounting for a minimum required number of customers per contact employee, customers were randomly approached in the store to fill out a questionnaire. For all the contact employees, 59 in total, seven different sales encounters for each contact employee were evaluated, which resulted in 413 questionnaires. Twenty-two could not be used because of missing data, so 391 questionnaires were usable. Although contact employees of two different stores of the company participated in this study, no significant differences between the stores were found.

\subsection{Descriptive analyses}

A number of variables have been included in the questionnaire in order to describe the sample characteristics. The respondents consisted of $49.6 \%$ women and $50.4 \%$ men. Their average age was between 35 and 45 years. With respect to education, it can be concluded that level of the respondents was quite high, as $37.8 \%$ of the respondents completing college or university and another $43.2 \%$ followed vocational education. The composition of the sample is representative for the overall population of customers of this furniture company, according to customer databases provided by the firm.

\section{Data analysis}

Our conceptual framework of the antecedents of customer and relationship satisfaction includes variables at two levels: the interaction and the employee level. Since employeespecific behaviors refer to an individual's performance tendency, we model them by aggregating the evaluations of the customers for each employee (in this study, seven customers per employee). This aggregation results in antecedents at the employee level. At the same time, interactionspecific antecedents are included in the model at the interaction level. These are evaluations of the customer which are not aggregated by employee, because we assume that these antecedents are interaction and not employee specific.

Empirical justification for aggregation was tested by means of an estimate $r_{W G(J)}$, as suggested by James et al. (1993). The interpretation of this estimate is similar to that of other reliability coefficients, with values of .70 as an acceptable level. For both constructs (competence and authenticity), an average estimate was obtained by averaging the $\left(r_{W G(J)}\right)$ estimates of the employees. All the averaged $\left(r_{W G(J)}\right)$ estimates of the aggregate variables showed values higher than .70. This indicates high agreement among several, different customers upon the competence and authenticity of a specific employee.

Data in a framework such as ours are designated as multilevel data (Bryk and Raudenbush, 1992). The levels are hierarchical, as interactions are nested within contact employees. The question of how to investigate hierarchically ordered systems, such as in this study, has been a concern for quite some time. Conventional statistical techniques (e.g., ordinary regression analysis) ignore this hierarchy and may, therefore, lead to incorrect results (Bryk and Raudenbush, 1992). Hierarchical linear models also called multilevel models, on the contrary, are an effective approach to deal with hierarchically nested data structures (e.g., Hofmann, 1997).

For the conduction of the multilevel analyses, the computer program MLwiN (Goldstein et al., 1998) was employed which computes iterative generalized least squares (IGLS) estimates by means of an iterative approach known as the EM algorithm (Bryk and Raudenbush, 1992; Goldstein, 1995).

Two-level models were specified where Level 2 contains 59 contact employees and Level 1 reflects 391 customers. The following strategy for model building was used. First of all, an intercept-only model (Model A) was estimated. This is a fully unconditional model (i.e., a model without predictors at any level), which decomposes the variance of the intercept into two independent random components, namely, $\Phi_{e 0}{ }^{2}$ at interaction level and $\Phi_{u 0}{ }^{2}$ at the employee level. This model represents the (unexplained) variation of the outcome variable (i.e., customer encounter or relationship satisfaction) at each level (interaction and contact employee). The second model (Model B) includes all covariates (i.e., age, gender) and the interaction-induced antecedents at the interaction level as well as the contact employee-specific antecedents at the employee level, to investigate how much of the total variance in customer encounter or relationship satisfaction can be explained by these added variables. In the multi-level models, the intercept was specified as a random coefficient (i.e., the coefficient was allowed to vary across contact employees). Therefore, a random parameter was specified at employee level. In Model B, the effects of the included predictor variables were constrained to be constant across employees. In theory, all effects of the coefficients could be specified as random effects. However, from a statistical viewpoint, this is not recommendable because it negatively affects model convergence and the stability of the parameter estimates (Bryk and Raudenbush, 1992). 


\subsection{Results}

Tables 2 and 3 present the results of our multilevel analyses regarding customer encounter satisfaction (Table 2) and relationship satisfaction (Table 3 ). In both tables, the findings of Model A indicate substantial variance at both levels, which implies that a multilevel approach is appropriate. With respect to the model fit, the $\Delta$ Deviance is significant which implies that the inclusion of the specified antecedents into the model reduces unexplained variance at both levels significantly. The predictive power of the different models can be compared by a likelihood ratio test (Bryk and Raudenbush, 1992). Deviance is computed for each model and the difference between the deviance statistics ( $\Delta$ Deviance) has a $\Pi^{2}$-distribution under $\mathrm{H}_{0}$ that the extended model (Model B) does not predict significantly better than the reduced model (Model A). Critical values of the $\Pi^{2}$-statistic mean that the reduced model is too simple a description of the data (Kleinbaum et al., 1998).

The results of Model B (Table 2) show that positive emotions have a significant positive impact and negative emotions have no significant impact on customer encounter satisfaction. Regarding our exploration of which contact employee performance dimensions influence customer encounter satisfaction, the results reveal that all dimensions have a significant impact. In addition, the results

Table 2

Customer encounter satisfaction

\begin{tabular}{|c|c|c|}
\hline & Model A & Model B \\
\hline \multicolumn{3}{|l|}{ Fixed effects } \\
\hline Constant & $4.985(.092)$ & $-2.907(.644)$ \\
\hline \multicolumn{3}{|l|}{ Interaction level } \\
\hline \multicolumn{3}{|l|}{ Performance } \\
\hline Mutual understanding & & $0.083(.037)^{*}$ \\
\hline Extra attention & & $0.246(.047)^{* *}$ \\
\hline Meeting minimum standards & & $0.395(.058)^{* *}$ \\
\hline \multicolumn{3}{|l|}{ Emotions } \\
\hline Positive emotions & & $0.217(.064)^{* *}$ \\
\hline Negative emotions & & $-0.137(.242)$ \\
\hline \multicolumn{3}{|l|}{ Contact employee level } \\
\hline \multicolumn{3}{|l|}{ Performance } \\
\hline Competence & & $0.353(.137)^{* *}$ \\
\hline Authenticity & & $0.234(.119)^{*}$ \\
\hline Age & & $0.008(.006)$ \\
\hline Experience & & $-0.017(.009)$ \\
\hline Sex & & $-0.120(.108)$ \\
\hline \multicolumn{3}{|l|}{ Random effects } \\
\hline $\begin{array}{l}\text { Variance } \\
\quad \text { (between contact employees) }\end{array}$ & $0.315(.091)$ & $0.003(.024)$ \\
\hline Variance (between interactions) & $1.066(.087)$ & $0.712(.058)$ \\
\hline \multicolumn{3}{|l|}{ Model fit } \\
\hline Deviance & 1110.050 & 894.935 \\
\hline Change deviance & & $215.115^{* *}$ \\
\hline Change $d f$ & & 10 \\
\hline Intraclass correlation & .23 & .004 \\
\hline
\end{tabular}

Table 3

Customer relationship satisfaction

\begin{tabular}{|c|c|c|}
\hline & Model A & Model B \\
\hline \multicolumn{3}{|l|}{ Fixed effects } \\
\hline Constant & $4.936(.073)$ & $1.202(.791)$ \\
\hline \multicolumn{3}{|l|}{ Interaction level } \\
\hline \multicolumn{3}{|l|}{ Performance } \\
\hline Mutual understanding & & $0.115(.043)^{* *}$ \\
\hline Extra attention & & $0.106(.053)^{*}$ \\
\hline Meeting minimum standards & & $0.052(.066)$ \\
\hline \multicolumn{3}{|l|}{ Emotions } \\
\hline Positive emotions & & $0.225(.073)^{* *}$ \\
\hline Negative emotions & & $-0.165(.275)$ \\
\hline \multicolumn{3}{|l|}{ Contact employee level } \\
\hline \multicolumn{3}{|l|}{ Performance } \\
\hline Competence & & $0.353(.172)^{*}$ \\
\hline Authenticity & & $-0.020(.150)$ \\
\hline Age & & $0.006(.008)$ \\
\hline Experience & & $-0.021(.011)$ \\
\hline Sex & & $-0.168(.136)$ \\
\hline \multicolumn{3}{|l|}{ Random effects } \\
\hline $\begin{array}{l}\text { Variance } \\
\quad \text { (between contact employees) }\end{array}$ & $0.145(.059)$ & $0.041(.036)$ \\
\hline Variance (between interactions) & $1.006(.082)$ & $0.902(.073)$ \\
\hline \multicolumn{3}{|l|}{ Model fit } \\
\hline Deviance & 1066.767 & 1004.488 \\
\hline Change deviance & & $62.279 * *$ \\
\hline Change $d f$ & & 10 \\
\hline Intraclass correlation & .13 & .044 \\
\hline
\end{tabular}

show that competence and authenticity are significant at the employee level and mutual understanding, extra attention, and meeting minimum standards at the interaction level. Finally, the findings of the three covariates age, gender, and experience show no significant impact on customer encounter satisfaction.

The results of Model B (Table 3) indicate a significant positive impact of positive emotions and no significant impact of negative emotions on customer relationship satisfaction. Regarding the exploration of which contact employee performance dimensions influence customer relationship satisfaction, the results reveal that only mutual understanding, extra attention, and competence have a significant impact. With respect to the significant antecedents, the results show again that competence is significant at the employee level and mutual understanding and extra attention at the interaction level. The findings of the three covariates age, gender, and experience show no significant impact on customer relationship satisfaction.

Furthermore, it can be observed that the estimated residual variances of Model B with respect to Model A at interaction level and at employee level are reduced by $33 \%$ and $99 \%$, respectively, for Table 2 , and $10 \%$ and $72 \%$, respectively, for Table 3 . This reveals that the added predictors explain primarily contact employee variance. 


\section{Discussion}

Our findings suggest that whereas all performance dimensions have a positive impact on customer encounter satisfaction, meeting minimum standards and authenticity do not influence customer relationship satisfaction significantly. Concerning meeting minimum standards, a possible explanation could be that customers, while recollecting multiple experiences to evaluate their relationship satisfaction, do not remember this aspect of employee performance. Research found that meeting minimum standards leaves the customer emotionally neutral and consequently is unlikely to be recalled as a memorable aspect of encounters (Price et al., 1995b; Westbrook and Oliver, 1991). Another possible explanation may be that in overall evaluations, past, good experiences may function as a buffer, such that despite a lesser experience, the customer's overall perceptions of minimum standards remain within the zone of tolerance (Zeithaml and Bitner, 1996).

An explanation of the finding regarding authenticity may be the nature of the interactions under study. These interactions can be described as discrete, pseudorelationships (Gutek et al., 1999). Research found that, although customers prefer an employee who is genuinely nice, authenticity is not that important in discrete services (Grayson, 1998). Pseudorelationships intend that customers do not anticipate future interaction with a particular employee, but with any contact employee of the firm (Gutek et al., 1999). Consequently, it could be that customers do not count on authenticity in each encounter, especially not if customers are aware of the employee-specific nature of authenticity and accordingly ascribe the genuine behavior to a particular employee.

Results of this study demonstrate that specifying contact employee performance into employee-specific and interaction-induced behaviors allow a better understanding of customer encounter and relationship satisfaction. The findings generally underscore the incremental value of a two-level approach to employee performance and indicate that both interaction-level and employee-level variables are crucial in explaining variance in customer satisfaction. It underscores the interactive nature of the encounter, and measurement of employee performance through customer satisfaction should take this interactive nature of the encounter into account.

Furthermore, our results reveal a significant influence of positive emotions on both types of satisfaction and no significant impact of negative emotions. The lack of influence of negative emotions is not that surprising. Studies about the impact of negative emotions on customer satisfaction found different results. Some studies found a significant influence of negative emotions on customer satisfaction (e.g., Westbrook, 1987). Others showed that negative emotions had no effect or can be tolerated by consumers, to some extent (e.g., Westbrook and Oli-ver, 1991).

\subsection{Theoretical implications and limitations}

Part of the strength of any research project is the recognition of its limitations. This may point out future research issues. First, our focus on a single industry may raise concerns about limited external validity. Constraining the study to a single industry eliminates problems associated with the effects of industry differences (cf. Hartline and Ferrell, 1996), but future research will have to reveal whether the results are generalizable to other settings.

Furthermore, to match customers with employees, customers completed the questionnaires in the store. This can cause feelings of unease with customers, because they have to evaluate the person they have just spoken to and who is still in the store. This may lead to social desirable answers to our questionnaire. To minimize biased responses, we only approached customers outside the view of the contact employee to ascertain confidentiality of the respondents. Future research should investigate if another approach could produce the same results.

In addition, by measuring relationship satisfaction as we did, the relative weight that the customers attach to different episodes remains unknown. Moreover, there may be a recency effect of the experience during the encounter on satisfaction with the relationship. Thus, to understand customers' current evaluation of the encounter and relationship, more information about their history is needed. Future research should take this history and customers' perceptions about 'normal' performance into account.

More research is also needed on the difference between employee-specific and interaction-induced behaviors of a contact employee. In this study, we estimated a model whereby the antecedents included at the individual level were different to the antecedents included at the aggregate level. Based on conceptual and methodological arguments, contact employee-specific antecedents were aggregated. However, the important empirical question whether these antecedents should be aggregated or not to explain maximal variance in customer satisfaction has been left unanswered. Although this is investigated in other contexts (Jonge et al., 1999), little is known about this kind of research in a customer-contact employee interaction context and this certainly needs more in-depth investigation.

\subsection{Managerial implications}

From a managerial perspective, our findings provide relevant insights to the many firms that redesign their role of the contact employee to make each encounter a memorable experience. It is clear from our data that a contact employee, who creates mutual understanding with the customer, responds to special requests, and is competent, increases customer encounter as well as relationship satisfaction. However, meeting minimum standards seems to be important in single encounters, but not to contribute to memorable encounters. This implies that in those instances 
when minimum standards cannot be attained (e.g., when the product is not available), customer relationship satisfaction can stay on a rather high level, when nevertheless mutual understanding, extra attention, and competence are experienced. Therefore, managers may encourage contact employees still to perform these latter behaviors.

In addition, it seems that although customers appreciate sincere people, they do not take it into account as an essential factor to form a relationship with a firm. This finding has managerial usefulness. Genuinely nice employees are likely to cost significantly more to select and train than employees who can successfully communicate a script (Leidner, 1993). Moreover, overall negative effects of authentic behavior for employees, like emotional exhaustion, have been documented (e.g., Grayson, 1998). Since relationship satisfaction appears not to be negatively influenced by a lack of authenticity, hiring people with the ability to perform a script and training contact employees to use scripts, might be a more effective investment for managers in discrete services than focusing on authenticity.

Regarding the coproduction of behaviors, managers may assist customers in their role in the interaction by providing them information about all their possibilities to contribute to the encounter. For instance, via advertising, they may encourage the customer to express special requests. However, to make these efforts effective, employees would need to be trained to become more sensitive in recognizing and responding to these contributions.

Furthermore, management should give employees insight into the interactive nature of some behaviors. This can make employees aware on how to influence customer satisfaction, with and without a contribution of the customer.

\section{Acknowledgements}

The authors thank Ad de Jong for his valuable suggestions in preparing this article.

\section{References}

Beatty SE, Mayer M, Coleman JE, Reynolds KE, Lee J. Customer-sales associate retail relationships. J Retail 1996;72:223-47.

Bitner MJ, Hubbert AR. Encounter satisfaction versus overall satisfaction versus quality: the customer's voice. In: Rust RT, Oliver RL, editors. Service quality, new directions in theory and practice. London: Sage, 1994. pp. 79-94.

Bitner MJ, Booms BH, Tetreault MS. The service encounter: diagnosing favorable and unfavorable incidents. J Mark 1990;54:71-84.

Bryk AS, Raudenbush SW. Hierarchical linear models: applications and data analysis methods. Newbury Park (CA): Sage, 1992.

Crosby LA, Evans KR, Cowles D. Relationship quality in services selling: an interpersonal influence perspective. J Mark 1990;54:68-81.

Czepiel JA. Service encounters and service relationships: implications for research. J Bus Res 1990;20:13-8.

Fornell C. A national customer satisfaction barometer: the Swedish experience. J Mark 1992;55:1-21.
Goff BG, Boles JS, Bellender DM, Stojack C. The influence of salesperson selling behaviors on customer satisfaction with products. J Retail 1997; $73: 171-83$.

Goldstein H. Multilevel statistical models. London: Griffin, 1995.

Goldstein H, Rasbach J, Plewis I, Draper D, Browne W, Yang M, Woodhouse G, Healey M. A user's guide to MlwiN. Multilevel Models Project Institute of Education, University of London, London, UK, 1998.

Gouldner AW. The norm of reciprocity: a preliminary statement. American Sociological Review, 176-7.

Grayson K. Customer responses to emotional labor in discrete and relational service exchanges. Int J Serv Ind Manage 1998;9:126-54.

Gurevitch ZD. The receiver's dilemma: impressions formed in response to impression management. Basic Appl Soc Psychol 1985;6:145-57.

Gutek BA, Bhappu AD, Liao-Troth MA, Cherry B. Distinguishing between service relationships and encounters. J Appl Psychol 1999;84: $218-33$.

Hartline MD, Ferrell OC. The management of customer-contact service employees. J Mark 1996;60:62-70.

Hofmann DA. An overview of the logic and rationale of hierarchical linear models. J Manage 1997;23:723-44.

Izard CE. Human emotions. New York: Plenum, 1977.

Izard CE. The psychology of emotions. New York: Plenum, 1991.

Jaccard J, Brinberg D, Dittus P. Couple decision making: individual- and dyadic-level analysis. In: Brinberg D, Jaccard J, editors. Dyadic decision making. New York: Springer, 1989. pp. 36-50.

James LR, Demaree RG, Wolf G. $r_{w g}$ : an assessment of within-group interrater agreement. J Appl Psychol 1993;78:306-9.

Johnson M, Zinkham GM. Emotional responses to a professional service encounter. J Serv Mark 1991;5:5-16.

Jonge J de, Breukelen GJP van, Landeweerd JA, Nijhuis FJN. Comparing group and individual level assessments of job characteristics in testing the job demand-control model: a multi-level approach. Hum Relat $1999 ; 52: 95-122$.

Kleinbaum DG, Kupper LL, Muller KE. Applied regression analysis and other multivariable methods. Boston: PWS-KENT Publishing, 1998.

Leidner R. Fast food, fast talk. Berkeley (CA): University of California Press, 1993.

Liljander V, Strandvik T. The nature of customer relationships in services. In: Schwarz TA, Bowen DE, Brown SW, editors. Advances in service marketing management, vol. 4. Greenwich (CT): JAI Press, 1995. pp. 65-85.

Oliver RL. Satisfaction, a behavioral perspective on the consumer. New York: McGraw-Hill, 1997.

Oliver RL, Swan JE. Consumer perceptions of interpersonal equity and satisfaction in transaction: a field study approach. J Mark 1989;53:21-35.

Price LL, Arnould EJ, Tierney P. Going to extremes: managing service encounters and assessing provider performance. J Mark 1995;59:83-97.

Price LL, Arnould EJ, Deibler SL. Consumers' emotional responses to service encounters: the influence of the service provider. Int J Serv Ind Manage 1995;6:34-63.

Reynolds KE, Beatty SE. Customer benefits and company consequences of customer-salesperson relationships in retailing. J Retail 1999;75: $11-32$.

Spiro RL, Weitz BA. Adaptive selling: conceptualization, measurement and nomological validity. J Mark Res 1990;27:61-9.

Szymanski DM. Determinants of selling effectiveness: the importance of declarative knowledge to the personal selling concept. J Mark 1988;52: $64-77$.

Weitz BA, Sujan H, Sujan M. Knowledge, motivation, and adaptive behavior: a framework for improving selling effectiveness. J Mark 1986;4:174-93.

Westbrook RA. Product/consumption-based affective responses and postpurchase processes. J Mark Res 1987;24:258-70.

Westbrook RA, Oliver RL. The dimensionality of consumption emotion patterns and customer satisfaction. J Consum Res 1991; 18:84-91.

Winsted KF. The service encounter in two cultures: a behavioral perspective. J Retail 1997;73:337-60.

Zeithaml VA, Bitner MJ. Services marketing. New York: McGrawHill, 1996. 